\title{
TESTIS GROWTH AND PLASMA LH CONCENTRATION FOLLOWING HEMICASTRATION AND ITS RELATION WITH FEMALE PROLIFICACY IN SHEEP
}

\author{
R. B. LAND AND W. R. CARR \\ A.R.C. Animal Breeding Research Organisation, Edinburgh EH9 37 Q
}

(Received 8th March 1975)

\begin{abstract}
Summary. The mean testis diameter of 20- to 25-week-old Blackface, Finn and Merino rams was ranked in the same order as the ovulation rates of females of their breeds. The removal of one testis at 12 or 16 weeks of age resulted in hypertrophy of the remaining testis. The relative increase in testis growth following hemicastration was greatest in the Merino rams (72\%), least in the Finns (42\%) and intermediate in the Blackfaces $(57 \%)$, so that it was inversely related to their breed ovulation rates. This hypertrophy was associated with increases in the concentration of plasma LH in all breed types.

The results indicate that differences in testis growth rate are associated with differences in gonadotrophic stimulation rather than intrinsic growth potential, and it is postulated that these may arise from breed differences in sensitivity to negative feed-back from the testes.
\end{abstract}

\section{INTRODUCTION}

Genetic selection for female reproductive performance is restricted by the absence of measures of the relative merits of potential sires. Testis growth (Land, 1973) and plasma LH concentration (Thimonier et al., 1972; Bindon \& Turner, 1974; Carr \& Land, 1975) of young male sheep have, however, been found to be related to the prolificacy of their female relatives. The use of these characteristics to aid genetic selection for female reproductive performance would be aided by an understanding of the sources of variation in the two traits, and in particular the relationships between them. The extent to which normal testis growth is restricted by the intrinsic growth potential of the testis or by the gonadotrophic stimulation was therefore studied by comparing testis growth in intact ram lambs of breeds of differing prolificacy with that following the removal of one testis at 12 or 16 weeks of age. The effects of hemicastration on the peripheral plasma LH concentrations were also examined.

\section{MATERIALS AND METHODS}

Ram lambs of the Finnish Landrace (Finn), Scottish Blackface (Blackface) and 
Tasmanian Merino (Merino) breeds were chosen because of the wide variation among the ovulation rates of their females, namely 2.9, 1.3 and 1.1 for the Finn, Blackface and Merino breeds, respectively (Wheeler \& Land, 1973). A total of $36 \mathrm{ram}$ lambs, born over a period of 7 weeks, were weaned and housed at the Animal Breeding Research Organisation, Dryden Field Laboratory, Roslin, Midlothian, during April and May 1973 by 8 weeks of age. Their body weight and testis diameter (recorded as the mean of both testes) were then measured at weekly intervals from 8 weeks ( \pm 3 days) of age. As the animals reached 12 weeks of age, they were grouped within breeds into trios in order of age. Within each trio, one animal was chosen at random to be hemicastrated at 12 weeks of age, one to be hemicastrated at 16 weeks, and one to be an intact control. In this way, any seasonal trends on the response to treatment would be similar in all groups. Some trios were however not completed and the groups finally contained four controls, four 12-week-old, and three 16-week-old hemicastrates for the Blackfaces; six controls, five 12-week-old and six 16-week-old hemicastrates for the Finns; and three controls, three 12-week-old and two 16-week-old hemicastrates for the Merinos.

Hemicastration was carried out using aseptic procedures, without opening the tunica vaginalis, under halothane anaesthesia induced by a mixture of Nembutal and pentothal, on the day following the 12- or 16-week measurement. Control animals were anaesthetized only. The testes were weighed after removal. Testis diameter and body weight was recorded at weekly intervals until 25 weeks of age when the experiment was terminated.

Peripheral blood samples were taken by acute puncture of the jugular vein using evacuated heparinized tubes on the $3 \mathrm{rd}, 4$ th, 5th and 6th days after surgery. Three samples were taken from each experimental animal and the corresponding control animal within a trio on each of the 4 days to give a total of twelve samples. Each control corresponded to two experimental animals so that one series of twelve samples was taken for each experimental animal, and two series of samples for each control. The samples were always taken during the period between 14.00 and 16.00 hours B.S.T., successive samples from individual animals being taken at 28- to 30-min intervals. Plasma was removed and frozen within $30 \mathrm{~min}$ of collection. The concentration of $\mathrm{LH}$ was measured by double-antibody radioimmunoassay (Carr \& Land, 1975), using a specific rabbit anti-ovine LH antiserum.

\section{RESULTS}

\section{Testis diameter}

The mean testis diameter and body weight of rams in each group is illustrated in Text-fig. 1. Hemicastration led to faster testis growth in rams of all six experimental groups when compared to their controls. This increase, expressed as the area under the curve describing testis growth for 9 weeks after hemicastration, was then compared with that of the controls. The areas, given in Table 1, measured the cumulative growth which had taken place after surgery, and it can be seen that growth in the unoperated controls $(\mathrm{C})$ between 12 and 21 weeks was greatest in the Finn lambs, least in the Merinos and inter- 
mediate in the Blackfaces. The percentage increase in growth rate of the remaining testis following hemicastration (Table 1) was, however, greatest in the Merino, least in the Finn and intermediate in the Blackface lambs, so that the ranking was reversed. From 16 to 25 weeks of age, although testis growth in the Finn was starting to level out and the testes of the Blackface and Merino controls grew more quickly, the increase following hemicastration was still less. The mean percentage response to hemicastration at the two ages was therefore greatest in the Merinos and least in the Finns.

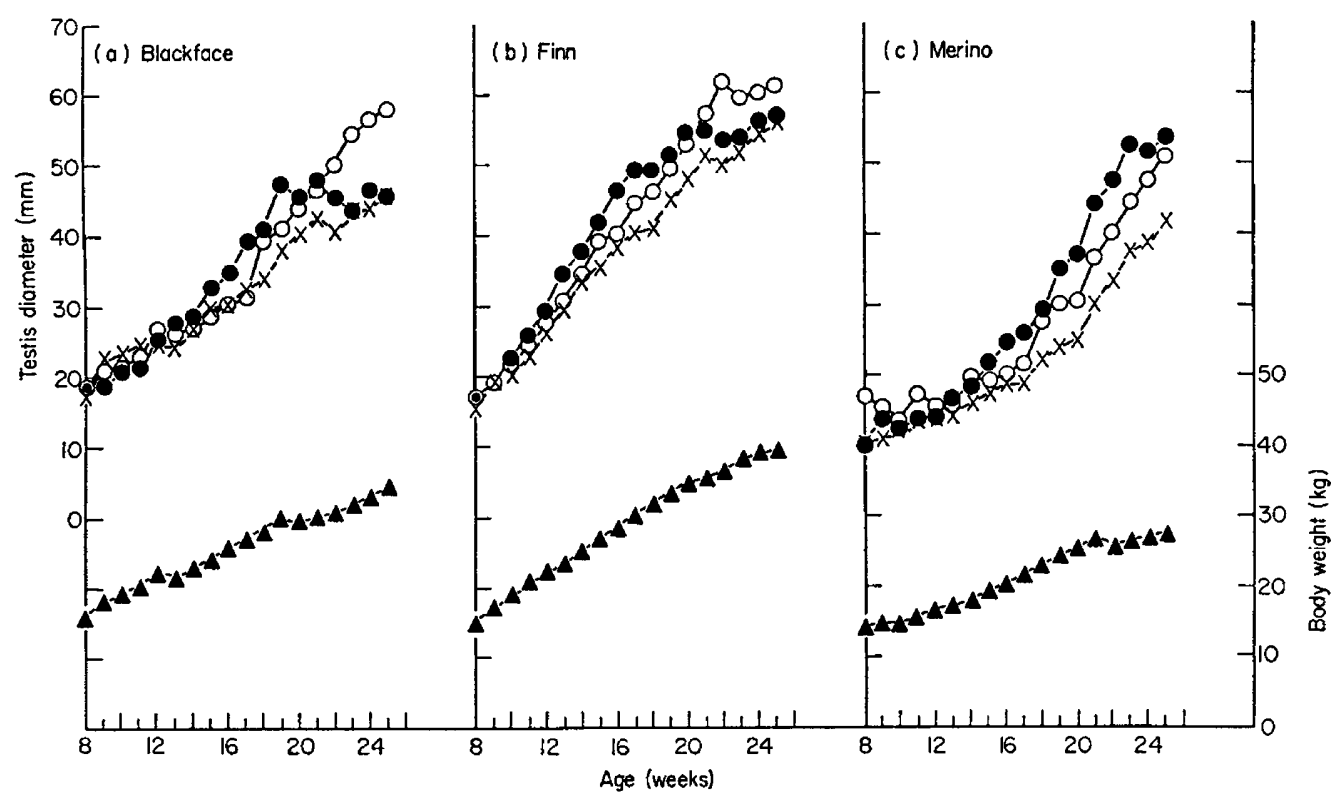

TExT-FIG. 1. The testis diameter of (a) Blackface, (b) Finn, and (c) Merino ram lambs, 8 to 25 weeks of age, which had been hemicastrated at $12(\bullet)$ or $16(0)$ weeks of age, and of untreated controls $(x) . \Delta$, Mean body weights of the rams in the three groups.

Table 1. The growth of the testes of intact control $(\mathrm{C})$ and hemicastrated $(\mathrm{H})$ ram lambs of the Blackface, Finn and Merino breeds from 12 to 21 and 16 to 25 weeks of age

\begin{tabular}{|c|c|c|c|c|c|c|c|}
\hline & \multicolumn{3}{|c|}{12 to 21 weeks } & \multicolumn{3}{|c|}{16 to 25 weeks } & \multirow{2}{*}{$\begin{array}{c}\text { Mean } \\
\text { increase } \\
(\%)\end{array}$} \\
\hline & $C$ & $H$ & $\%$ & $C$ & $H$ & $\%$ & \\
\hline $\begin{array}{l}\text { Blackface } \\
\text { Finn } \\
\text { Merino }\end{array}$ & $\begin{array}{r}10 \cdot 4 \\
15 \cdot 6 \\
8 \cdot 6\end{array}$ & $\begin{array}{l}15 \cdot 0 \\
20 \cdot 7 \\
16 \cdot 4\end{array}$ & $\begin{array}{l}44 \cdot 2 \\
32 \cdot 6 \\
90 \cdot 6\end{array}$ & $\begin{array}{l}11 \cdot 6 \\
11 \cdot 1 \\
12 \cdot 7\end{array}$ & $\begin{array}{l}19 \cdot 8 \\
16 \cdot 9 \\
19 \cdot 6\end{array}$ & $\begin{array}{l}70 \cdot 6 \\
52 \cdot 2 \\
54 \cdot 3\end{array}$ & $\begin{array}{l}57 \cdot 4 \\
42 \cdot 4 \\
72 \cdot 4\end{array}$ \\
\hline
\end{tabular}

The testis growth was measured as units of area under the growth curves in Text-fig. 1 ( 1 unit $=2.62 \mathrm{~mm}$.days) The $\%$ increased growth of the testes after hemicastration is relative to that of the controls.

The statistical significance of these effects was assessed by least squares analysis. The testis diameter of the control and hemicastrated rams of the three breeds was fitted for breed, treatment and their interaction at each week from 
20 to 25 weeks of age while using the 12-week weight as a covariate to reduce the variation between individuals. The fitted values for testis diameter so obtained at 20 and 25 weeks of age are given in Table 2. For control animals over this period, the means of the weekly fitted diameters were $50 \cdot 1,42 \cdot 1$ and 37.7 $\mathrm{mm}$ based on a log scale for the Finn, Blackface and Merino ram lambs, respectively. Differences in the effects of treatment on the final testis size of the three breeds correspond to a breed by treatment interaction, for 4 and 26 d.f., for this assesses the extent to which the three breeds respond differently to hemicastration. The $\mathrm{F}$ values for this interaction were $0.96,2 \cdot 49,3.48,3 \cdot 30$, 2.03 and 3.37 for the Weeks 20 to 25 inclusive, where $\mathrm{F}>2.74$ corresponds to $P<0.05$, and the probability of the observed differences occurring by chance was therefore around $0 \cdot 05$.

Table 2. The mean fitted values for the testis diameter ( $\mathrm{mm}$ ) of Blackface, Finn and Merino lambs at 20 and 25 weeks of age after hemicastration at $12(\mathrm{H} 12)$ or $16(\mathrm{H} 16)$ weeks of age

\begin{tabular}{lccccccc}
\hline & \multicolumn{3}{c}{20 weeks of age } & & \multicolumn{3}{c}{25 weeks of age } \\
\cline { 2 - 5 } \cline { 7 - 8 } & Control & $H 12$ & $H 16$ & & Control & $H 12$ & $H 16$ \\
\hline Blackface & 39 & 44 & 43 & & 46 & 45 & 58 \\
Finn & 47 & 51 & 50 & & 54 & 55 & 59 \\
Merino & 32 & 42 & 33 & & 43 & 55 & 52 \\
\hline
\end{tabular}

The effects of 12-week weight on testis diameter declined as the lambs grew older. With 1 and 25 d.f. the $F$ values fell from $17 \cdot 45$ at 20 weeks to $1 \cdot 10$ at 25 weeks of age. Although animals which were heavier at 12 weeks of age therefore had faster testis growth rates, the final (i.e. 25-week) diameters appeared to be independent of early body growth.

\section{Testis weight}

The mean weights of the testis removed at 12 and 16 weeks of age are given in Table 3. As for the fitted testis diameters, the three breeds were ranked Finn, Blackface, Merino, at both ages. The relationship between testis weight and testis diameter the day before hemicastration is illustrated in Text-fig. 2. The correlation between the two variables was 0.94 , based on 25 pairs of observations $(P<0.001)$, and thus approximately $90 \%$ of the variation in the two characters was common to both. The regression of testis weight on testis diameter, assuming linearity, was $2.05 \mathrm{~g} / \mathrm{mm}$ with a constant of $-23 \mathrm{~mm}$.

\section{Concentrations of $L H$}

The mean LH concentration in the twelve samples was used for the calculation of breed means given in Table 3. Some samples were unfortunately lost between collection and assay. The plasma concentrations were not normally distributed, and showed considerable scatter. The means have not been compared statistically. The data indicate that, in all three breed types and at both ages, hemicastration was followed by an elevation of plasma LH concentrations. Furthermore, when the two age groups were pooled within breeds, the mean increase 
Table 3. The mean ( \pm S.E.) weight of the testes of Blackface, Finn and Merino lambs at hemicastration at 12 or 16 weeks of age and the LH levels at these times

\begin{tabular}{|c|c|c|c|}
\hline & Blackface & Finn & Merino \\
\hline $\begin{array}{c}\text { Testis wt }(\mathrm{g}) \\
12 \text { weeks } \\
16 \text { weeks }\end{array}$ & $\begin{array}{l}22 \cdot 5 \pm 1 \cdot 5 \\
29 \cdot 2 \pm 13 \cdot 2\end{array}$ & $\begin{array}{l}29 \cdot 7 \pm 3 \cdot 7 \\
64 \cdot 5 \pm 11 \cdot 3\end{array}$ & $\begin{array}{l}3.0 \pm 0.2 \\
8.9 \pm 0.2\end{array}$ \\
\hline $\begin{array}{l}\text { LH }(\mathrm{ng} / \mathrm{ml} \text { plasma) } \\
12 \text { weeks } \\
\text { Control }(\mathrm{C}) \\
\text { Hemicastrated }(\mathbf{H}) \\
\text { H-C }\end{array}$ & $\begin{array}{l}0.5(36) \\
2.1(36) \\
1.6\end{array}$ & $\begin{array}{l}3.8(48) \\
5.5(48) \\
1.7\end{array}$ & $\begin{array}{l}1.2(24) \\
2.8(24) \\
1.6\end{array}$ \\
\hline $\begin{array}{l}16 \text { weeks } \\
\text { Control }(\mathrm{C}) \\
\text { Hemicastrated }(\mathrm{H}) \\
\mathrm{H}-\mathrm{C}\end{array}$ & $\begin{array}{l}2.4(36) \\
3.2(24) \\
0.8\end{array}$ & $\begin{array}{l}2 \cdot 4(60) \\
4 \cdot 1(60) \\
1 \cdot 7\end{array}$ & $\begin{array}{l}1.3(12) \\
2.9(12) \\
1.6\end{array}$ \\
\hline Pooled increase $(\%)$ & 83 & 55 & 128 \\
\hline
\end{tabular}

Values in parentheses are the numbers of samples.

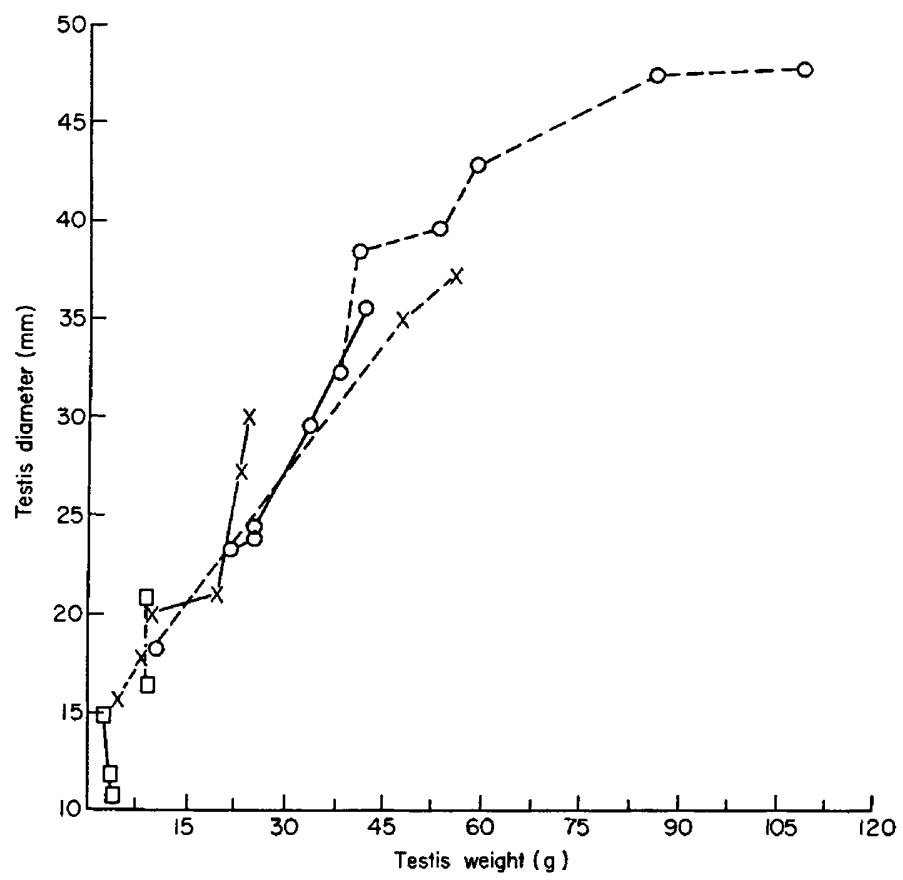

Texr-Fig. 2. The weight of testes removed from Blackface $(x)$, Finn $(0)$ and Merino (D) lambs at $12(-)$ or $16(--)$ weeks of age compared with the testicular diameter the day before hemicastration $(r=0.94$; diameter $(\mathrm{mm})=15.4+3.84 \times$ weight $(\mathrm{g}))$. 
observed relative to control concentrations was greatest in the Merino lambs, and least in the Finns. At 12 weeks of age the LH concentration in the plasma of the control Finns was higher than that of the Merinos and Blackfaces, but had declined by 16 weeks of age.

\section{DISGUSSION}

The diameter of the testes of intact ram lambs of the Scottish Blackface, Finnish Landrace and Tasmanian Merino breeds is positively related to the ovulation rates of the female of these breed types. The result therefore confirms the observation that the testes of Finn ram lambs are of greater diameter than those of Merinos (Land, 1973), and reinforces the relationship between female and male characteristics with the observation that the Blackface lambs were intermediate for both. The observation that testis diameter is highly correlated with testis weight, and that a single curve is adequate to describe the relationships between the two variables for each of the six breed and age combinations, confirms the use of testis diameter as an estimate of testis size.

The removal of one testis was followed by a relative increase in the growth of the remaining testis, in all three breeds. The relative increase or hypertrophy of the remaining testis was, however, breed dependent and, in our study, inversely related to the ovulation rate of the breed, the hypertrophy being greatest in the Merino rams, in which breed the ovulation rate is lowest, and vice versa in the Finns. The slow growth of the testes of the Merino ram lambs is not therefore due to an intrinsically low growth potential, but is partly under the control of the testes themselves. It is known that testis growth in the sheep is dependent upon gonadotrophic stimulation (Courot, 1967). The increase in the concentration of plasma $\mathrm{LH}$ after hemicastration observed in the ram lambs of the present study and in adult Ile-de-France rams (Hochereau-de Reviers et al., 1976) indicates that the testicular hypertrophy is dependent upon increased gonadotrophic stimulation. The feed-back effects of the testis on the secretion of gonadotrophins by the hypothalamo-hypophysial axis may, therefore, be considered to be greater in the Merino lambs than in the Finns. This may arise from a higher production of feed-back steroids from the testes of the Merino lambs, but in view of the slow growth rate of the testes and the low libido (R. B. Land, unpublished) of these lambs it is more likely that the secretion of gonadotrophins is more sensitive to negative feed-back stimuli from the testes. The result is therefore compatible with the hypothesis that the removal of one testis reduces the feed-back, and indicates that this has a greater effect on Merino than Finn rams, with the Blackfaces being intermediate. The present betweenbreed studies also indicate that the within-breed correlation between testis growth and LH concentration reported by Carr \& Land (1975) may be a causative relationship.

The present results support the concept that high ovulation rate in the female is related to high testis growth rate in the male. In addition, however, they also indicate that the gonadotrophic stimulation of the ram lambs of the three breeds studied is inversely related to the negative feed-back effects of their testes on the release of gonadotrophins. It is possible that sensitivity to feed- 
back from the gonad may be the factor responsible for the relationship between gonadal activity of genetically related males and females.

\section{ACKNOWLEDGMENTS}

We wish to thank Miss Marjorie Fordyce and Mr G. Baxter for skilled technical assistance, and Mr D. I. Sales for the analysis of variance. We are grateful to Dr R. J. Scaramuzzi for providing the rabbit anti-ovine LH antiserum.

\section{REFERENCES}

Bindon, B.M. \& TURner, H.N. (1974) Plasma LH of the prepubertal lamb: a possible early indicator of fecundity. F. Reprod. Fert. 39, 85-88.

CARR, W.R. \& LAND, R.B. (1975) Plasma luteinizing hormone levels and testis diameters of ram lambs of different breeds. F. Reprod. Fert. 42, 325-333.

Courot, M. (1967) Endocrine control of the supporting and germ cells of the impuberal testis. F. Reprod. Fert., Suppl. 2, 89-101.

Hochereau-de Reviers, M.T., Loir, M. \& Pelletier, J. (1976) Seasonal variations in the response of the testis and LH levels to hemicastration in adult rams. F. Reprod. Fert. 46, 203-209.

LAND, R.B. (1973) The expression of female sex-limited characters in the male. Nature, Lond. 241, 208209.

Thimonier, J., Pelletter, J. \& Land, R.B. (1972) The concentrations of plasma LH in male and female lambs of high and low prolificacy breed types. F. Reprod. Fert. 31, 498, Abstr.

WhEELER, A.G. \& LAND, R.B. (1973) Breed and seasonal variation in the incidence of oestrus and ovulation in the sheep. F. Reprod. Fert. 35, 583-584, Abstr. 